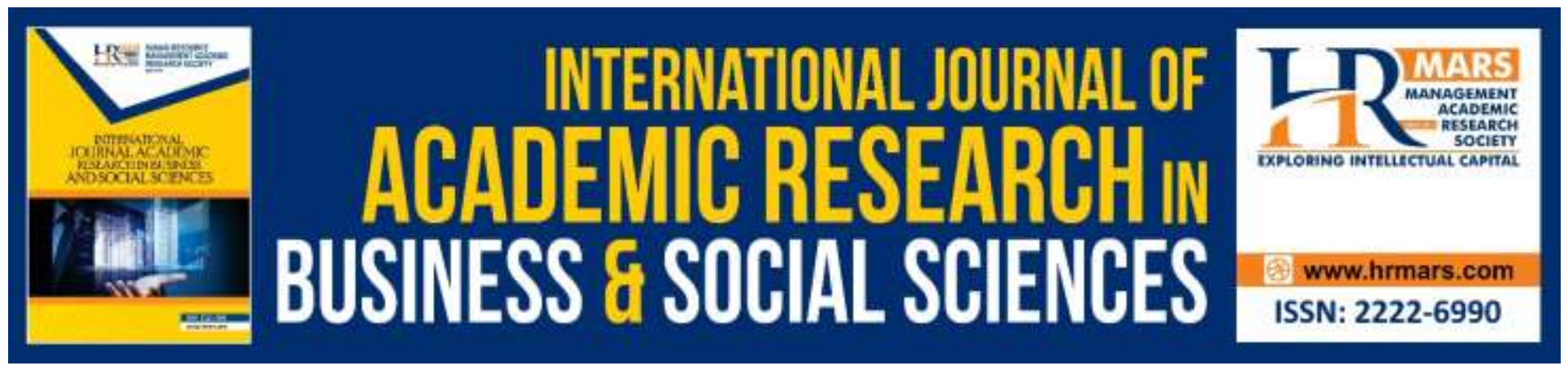

\title{
The Validity of the Monitoring Kit (Courseware) for Basic Electrical Wiring Training among Malaysian Premier Polytechnics
}

Noor Aida Aslinda Norizan, Che Ghani Che Kob, Halimaton Shamsuddin \& A. Shah

To Link this Article: http://dx.doi.org/10.6007/IJARBSS/v9-i7/6161

DOI: $10.6007 /$ IJARBSS/v9-i7/6161

Received: 22 May 2019, Revised: 19 June 2019, Accepted: 27 June 2019

Published Online: 13 July 2019

In-Text Citation: (Norizan, Kob, Shamsuddin, \& Shah, 2019)

To Cite this Article: Norizan, N. A. A., Kob, C. G. C., Shamsuddin, H., \& Shah, A. (2019). The Validity of the Monitoring Kit (Courseware) for Basic Electrical Wiring Training among Malaysian Premier Polytechnics. International Journal of Academic Research in Business and Social Sciences, 9(7), 692-699.

Copyright: (C) 2019 The Author(s)

Published by Human Resource Management Academic Research Society (www.hrmars.com)

This article is published under the Creative Commons Attribution (CC BY 4.0) license. Anyone may reproduce, distribute, translate and create derivative works of this article (for both commercial and non-commercial purposes), subject to full attribution to the original publication and authors. The full terms of this license may be seen

at: http://creativecommons.org/licences/by/4.0/legalcode

Vol. 9, No. 7, 2019, Pg. $692-699$.

Full Terms \& Conditions of access and use can be found at http://hrmars.com/index.php/pages/detail/publication-ethics 


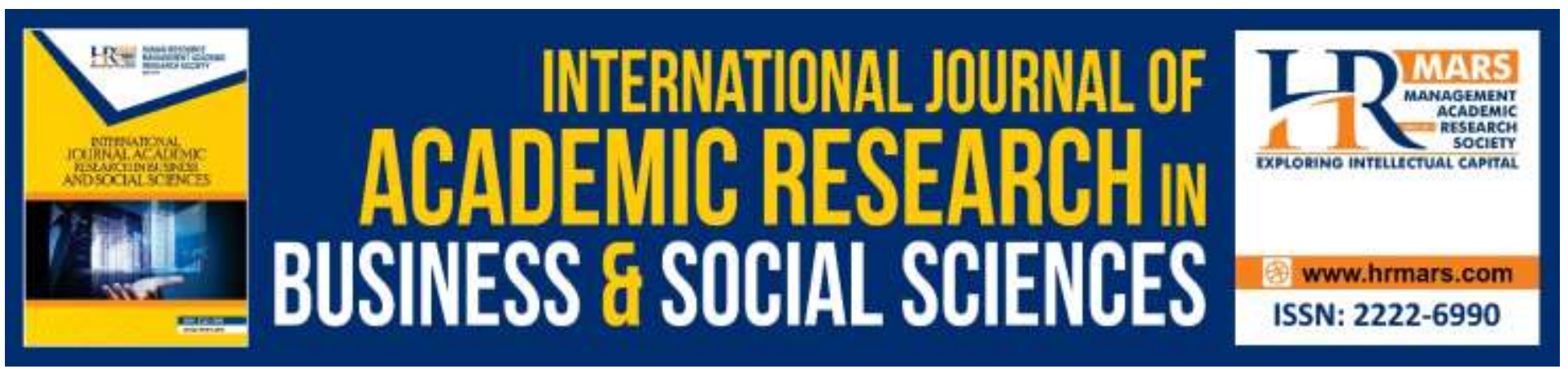

\title{
The Validity of the Monitoring Kit (Courseware) for Basic Electrical Wiring Training among Malaysian Premier Polytechnics
}

\author{
Noor Aida Aslinda Norizan, Che Ghani Che Kob*, Halimaton \\ Shamsuddin \& A. Shah \\ Department of Engineering Technology, Faculty of Technical and Vocational, Universiti Pendidikan \\ Sultan Idris, Tanjung Malim 35900, Malaysia \\ Email: cheghani@ftv.upsi.edu.my
}

\begin{abstract}
This research is done as to test the validity of the content in the Monitoring Kit (Courseware)for the basic electrical wiring training. A set of questionnaire of the validity of the module's content based on Russell (1974) contains 18 questions. The design review with the questionnaire using Likert scale is implemented on five expert panels through intended sampling. All five experts are required to fill the fixed characteristics such as they must be the lecturers in polytechnics, must be teaching in the electrical field, have the teaching experience of more than years and also their consent to be included in this study. Results show that the developed courseware has a high validity of 96 percent. However, there are several aspects to be improved before the Monitoring Kit (Courseware) is used during the teaching and learning session in the classroom. Thus, Monitoring Kit (Courseware) product can be proceeded by doing a pilot study using Monitoring Kit (Courseware) on the students from Electrical Engineering Department in Malaysian Premier Polytechnics.

Keywords: Validity, Courseware, Module, Monitoring Kit, Learning Aid, Electric, Teaching And Learning

\section{Introduction}

Validity is the ability of a measurement to measure the real value of a concept in a hypothesis. Validity refers to the concept of measuring what is supposed to be measured (Berawi, 2017; Konting, 1990). Darusalam and Hussin (2016), states that the higher the value and the level of validation, the more concrete the data acquired to produce a good quality research. According to Azman and Mustapha (2016); Noah and Ahmad (2005), validity could be marked high if the built instruments are really able to truly measure the concept stated in the hypothesis. Hashim, Ramli (2007), states that researchers are required to ensure that the tools and instruments are built with a certain level of validation. This
\end{abstract}


INTERNATIONAL JOURNAL OF ACADEMIC RESEARCH IN BUSINESS AND SOCIAL SCIENCES Vol. 9, No. 7, July, 2019, E-ISSN: 2222-6990 @ 2019 HRMARS

means that the research results will be meaningless if the measuring tools used are not able to measure what they are supposed to measure. Hence, every measured aspect needs to fill the required characteristics and specifications.

A module's validity refers to the accuracy of the concept and the content of the module. This is because the measuring tool and module are the tools, sources and materials that would guide a module designer to get various information and data regarding the studies and researches done (Noah \& Ahmad, 2005). Thus, Konting (2000) recommends that the researchers who are developing modules should get feedbacks and opinions from the experts to determine the validity of the module. This is in line with what is stated by Effendi, Idris, Rahman and Khairani (2017), who says that the validity of the content is usually measured with experts' evaluation that would look into the agreed scale for every content measured. The content validity of the module would be considered good if it can measure all of its content accurately.

\section{Literature Review}

Electrical Technology is one of the programs offered in most Malaysian polytechnics. It is an important program in shaping students' future career. However, there are several problems that emerge during the teaching and learning process, especially in the Basic Electrical Wiring Course. Graduates are said to be unable to show the ability required by the working sector nor do they are able to master the level of excellent social morality skill in the society (Hussain et al., 2008).

One of the factors that contributes to this is the lack of facilities that cause the process of teaching and learning to only be carried out traditionally. Observations are done in between the electrical lecturers. It is stated that the teaching and learning process of the course only includes the traditional method with whiteboard as the teaching aid and the teaching method used is only the teacher and student centered learning. Results from the study done by Arsat dan Rasid (2010), show that the respondents agreed that interest is important to prepare the students of Electrical and Electronical Engineering in shaping their own future career. Hence, the courseware for the basic electrical wiring is developed. However, the aspect that should be focused on more in this courseware development is the validity of the content, in order to produce a high quality courseware.

\section{Methodology}

This research was carried out using experimental design method and observational quantitative approach. Researchers analysed the validity from experts quantitatively through cumulative scores. While planning on developing the courseware (monitoring kit), researchers had carried out library based research beforehand. Then, the validity of the module was carried out to elicit some thoughts and feedback from the chosen experts. According to Lawshe (1975), the term expert is to be mentioned as Content Evaluation Panel. The experts are those who are involved with the researched field to help determine the suitability of the developed content (Effendi et al., 2017). The experts were chosen based on the criteria such as the fields, amount of published and experience in their work (Rubio, Berg-Weger, Tebb and Rauch, 2003).

Meanwhile, the number of expert panels depended on the level of expertise and knowledge of the experts. Quite a number of panels were chosen in the past. According to Darusalam and Hussin 
INTERNATIONAL JOURNAL OF ACADEMIC RESEARCH IN BUSINESS AND SOCIAL SCIENCES Vol. 9, No. 7, July, 2019, E-ISSN: 2222-6990 (C) 2019 HRMARS

(2018), the number of panels should include at least three people from the field. This is in line with the opinion from Rubin et al., (2003) and Lynn, (1986) who suggested that at least three experts for each field is sufficient. The previous works had shown that various numbers of panels were used in researches, as in the research carried out by Ibrahim, Arip and Bitamam (2014), three expert panels were involved while in the research by Yahya, (2015); Ghani and Aris, (2012), four experts were involved.

Table 1 : Biodata of the Validity Experts Panel

\begin{tabular}{|c|c|c|}
\hline Num. & Expert Field & Experience \\
\hline Panel 1 & $\begin{array}{l}\text { Electrical } \\
\text { Engineering }\end{array}$ & $\begin{array}{l}\text { - A lecturer in Malaysian Polytechnics } \\
-28 \text { years of teaching experience in the field } \\
\text {-Vocational Training Officer (VTO) } \\
\text {-Safety Journal in wiring workshops }\end{array}$ \\
\hline Panel 2 & $\begin{array}{l}\text { Electrical } \\
\text { Engineering }\end{array}$ & $\begin{array}{l}\text { - A lecturer in Malaysian Polytechnics } \\
\text { - } 16 \text { years of teaching experience in the field }\end{array}$ \\
\hline Panel 3 & $\begin{array}{l}\text { Education in } \\
\text { Electrical } \\
\text { Engineering }\end{array}$ & $\begin{array}{l}\text { - A lecturer in Malaysian Polytechnics } \\
\text { - } 25 \text { years of teaching experience in the field }\end{array}$ \\
\hline Panel 4 & $\begin{array}{l}\text { Education in } \\
\text { Electrical } \\
\text { Engineering }\end{array}$ & $\begin{array}{l}\text { - A lecturer in Malaysian Polytechnics } \\
\text { - } 17 \text { years of teaching experience in the field } \\
\text { - Research on Worker's Safety and Health Act } 1994 \\
\text { - CIDB Competency Certificate }\end{array}$ \\
\hline Panel 5 & $\begin{array}{l}\text { Electrical } \\
\text { Engineering }\end{array}$ & $\begin{array}{l}\text { - A lecturer in Malaysian Polytechnics } \\
\text { - } 16 \text { years of teaching experience in the field }\end{array}$ \\
\hline
\end{tabular}

In the context of this research, content validity was given to five person experts that who were chosen through intended sampling. The choosing criteria of the panels include (i) lecturers in polytechnics, (ii) are teaching in electrical field (iii) have an experience of more than ten years (iv) the consent from the experts to be included in the research. All six expert panels should fulfill these characteristics that fixed by the researcher. The validity of the experts was carried out to determine 
INTERNATIONAL JOURNAL OF ACADEMIC RESEARCH IN BUSINESS AND SOCIAL SCIENCES Vol. 9, No. 7, July, 2019, E-ISSN: 2222-6990 @ 2019 HRMARS

whether the content of the module could really be tested based on the construct that was supposed to be measured (Goodwin, 2007). Table 1 had shown the biodata of the panels involved in this research.

A questionnaire on the validity of the module's content based on Russell (1974), had been altered and given to the panel of experts for them to evaluate the content of the developed module. The evaluation was done using Likert scale with ten chosen points of (1) representing totally disagree and (10) representing totally agree. Noad and Ahmad (2005), stated that the validity questionnaire is built specifically to test the validity of the content of certain module and the high validity of content of $70 \%$ would be considered to have mastered or achieved the highest level of validation. A good content validity is determined by the evaluation percentage from the panel of experts chosen through the questionnaires, given out using the formula below:

$$
\text { Mastery Level of Content Validity }=\frac{\text { Total Experts Score }}{\text { Total Score }} \quad \times 100 \%
$$

\section{Data Analysis}

Based on the result obtained by all of the experts, the validity value of the developed courseware for basic electrical wiring is as shown in Table 1. Result shows that the minimum percentage of the validity is 94 percent while the maximum percentage of validity is 100 percent. Based on the overall percentage analysis, the developed courseware content is at 96 percent. meanwhile, the validity value has surpassed 70 percent. This is same opinion with Noad and Ahmad (2005), who stated the content validity of a module has achieved a high level of validity as the percentage surpasses 70 percent. This shows that the developed courseware content can be trusted and has a high consistency because the courseware is developed based on the syllabus. It can also solve the problems faced by the students and teachers in the teaching and learning process. 
INTERNATIONAL JOURNAL OF ACADEMIC RESEARCH IN BUSINESS AND SOCIAL SCIENCES

Vol. 9, No. 7, July, 2019, E-ISSN: 2222-6990 (C) 2019 HRMARS

Table 2 : The Validity Value of The Overall Courseware

\begin{tabular}{|c|c|c|c|c|c|c|c|c|}
\hline \multirow{2}{*}{ Num. } & \multirow{2}{*}{ Statement } & \multicolumn{5}{|c|}{ Validity (\%) } & \multirow{2}{*}{$\begin{array}{c}\text { Percentage } \\
\text { (\%) }\end{array}$} & \multirow{2}{*}{$\begin{array}{l}\text { Experts' } \\
\text { View }\end{array}$} \\
\hline & & 1 & 2 & 3 & 4 & 5 & & \\
\hline 1. & $\begin{array}{l}\text { Courseware helps students to solve } \\
\text { problems. }\end{array}$ & 100 & 100 & 90 & 100 & 90 & 96 & Accepted \\
\hline 2. & $\begin{array}{l}\text { Courseware is suitable to be used as } \\
\text { teaching materials. }\end{array}$ & 100 & 100 & 90 & 90 & 90 & 94 & Accepted \\
\hline 3. & Courseware encourages self learning & 100 & 100 & 90 & 90 & 90 & 94 & Accepted \\
\hline 4. & $\begin{array}{l}\text { Courseware helps in increasing } \\
\text { students' understanding }\end{array}$ & 100 & 100 & 90 & 100 & 90 & 96 & Accepted \\
\hline 5. & $\begin{array}{l}\text { Courseware helps to solve a } \\
\text { practical problem faster }\end{array}$ & 100 & 100 & 90 & 90 & 90 & 94 & Accepted \\
\hline 6. & $\begin{array}{l}\text { Courseware contains of suitable } \\
\text { syllabus, in line with the course }\end{array}$ & 100 & 100 & 90 & 90 & 90 & 94 & Accepted \\
\hline 7. & $\begin{array}{l}\text { Explanation of the safety workshop } \\
\text { is clear in the courseware }\end{array}$ & 100 & 100 & 90 & 100 & 100 & 98 & Accepted \\
\hline 8. & $\begin{array}{l}\text { The names of the accessories are } \\
\text { accurate }\end{array}$ & 100 & 100 & 100 & 100 & 100 & 100 & Accepted \\
\hline 9. & $\begin{array}{l}\text { The accessories used in the } \\
\text { courseware are suitable to use }\end{array}$ & 100 & 100 & 90 & 100 & 90 & 96 & Accepted \\
\hline 10. & $\begin{array}{l}\text { Courseware content covers the } \\
\text { syllabus }\end{array}$ & 100 & 100 & 90 & 100 & 80 & 94 & Accepted \\
\hline 11. & Courseware is easy to use in lesson & 100 & 100 & 90 & 100 & 90 & 96 & Accepted \\
\hline 12. & $\begin{array}{l}\text { The video displayed is interesting for } \\
\text { students }\end{array}$ & 100 & 100 & 90 & 100 & 90 & 96 & Accepted \\
\hline 13. & $\begin{array}{l}\text { Courseware gives an impression to } \\
\text { students }\end{array}$ & 100 & 100 & 90 & 100 & 90 & 96 & Accepted \\
\hline 14. & $\begin{array}{l}\text { Courseware reduces accidents in } \\
\text { workshops }\end{array}$ & 100 & 100 & 90 & 90 & 90 & 94 & Accepted \\
\hline 15. & $\begin{array}{l}\text { Courseware saves the time to check } \\
\text { on the circuit by every student }\end{array}$ & 100 & 100 & 90 & 90 & 90 & 94 & Accepted \\
\hline 16. & $\begin{array}{l}\text { Courseware reduces the use of } \\
\text { materials and accessories }\end{array}$ & 100 & 100 & 100 & 90 & 100 & 98 & Accepted \\
\hline 17. & The words used are correct & 100 & 100 & 100 & 100 & 100 & 100 & Accepted \\
\hline 18. & $\begin{array}{l}\text { The language used is suitable with } \\
\text { the students' level }\end{array}$ & 100 & 100 & 90 & 100 & 100 & 98 & Accepted \\
\hline & Overall & 100 & 100 & 92 & 96 & 92 & 96 & Accepted \\
\hline
\end{tabular}


INTERNATIONAL JOURNAL OF ACADEMIC RESEARCH IN BUSINESS AND SOCIAL SCIENCES

Vol. 9, No. 7, July, 2019, E-ISSN: 2222-6990 @ 2019 HRMARS

\section{Conclusions}

As a conclusion, this courseware has successfully obtained the unanimous evaluation from the experts in developing it. This research is able to contribute to the production of a courseware that has an evaluated validity. Based on the result, it is proven that the courseware has been developed systematically and according to the procedures to develop a module scientifically. The research process has proven that the courseware has a very high validity value. This is why the courseware is ready to be tested to see the ability and the impact on getting it to be a high quality product. It is hoped that the courseware could be of help in making the process of teaching and learning in the classroom smoother and easier. Other than that, it is hoped that this courseware could increase the students' interest in the electrical wiring course, in order to produce graduates that are capable to excel in their working sector.

\section{Acknowledgments}

The authors wish to thanks the Education Ministry of Malaysia for founding this research under code 2018-0166-106-01 and also thanks to students and teachers for their willingness to become research respondents and assist in the success of this study.

\section{References}

Arsat, M., \& Rasid, N. A. (2010). Faktor Kesediaan Pelajar Kejuruteraan Elektrik Dan Elektronik Dalam Pembentukan Kerjaya. Diperoleh Jun 29, 2019 daripada http://eprints.utm.my/10308/2/Nor_Azura_Binti_Rasid.pdf.

Azman, M. N. A., \& Mustapha, R. (2014) Pendidikan Teknikal dan Voksaional; Pendekatan Penyelidikan Analisis dan Interpretasi. Perak: Universiti Pendidikan Sultan Idris.

Berawi, F. M. (2017). Metodologi Penyelidikan : Panduan Menulis Tesis. Sintok : Universiti Utara Malaysia.

Darusalam, G. \& Hussin, S. (2016). Metodologi Penyelidikan dalam Pendidikan. Kuala Lumpur : Penerbit Universiti Malaya.

Darusalam, G. \& Hussin, S. (2018). Metodologi Penyelidikan dalam Pendidikan. Kuala Lumpur: Penerbit Universiti Malaya.

Efendi, M., Idris, H., Rahman, N. A., Khairani, A. Z. (2017). Kesahan Kandungan Pakar Instrumen Ikrar bagi Pengukuran AQ Menggunakan Nisbah Kesahan Kandungan. Global Eduation, Comman Wealth and $2^{\text {nd }}$ Cultural Adversity, 979-997.

Ghani, F. A. \& Aris, M. (2012). Pembinaan Kesahan Dan Kebolehpercayaan Modul Kemahiran Mengawal Stress Kehidupan Guru. Jurnal Teknologi, 58(1), 45-50.

Goodwin, C. J. (2007). Research in Psychology Methods and Design. New York: John Wiley and Sons.

Hashim, A. Y. S., Boon, Y, \& Ramli, J. (2007). Menguasai Penyelidikan Dalam Pendidikan. Kuala Lumpur: PTS Professional Publishing Sdn. Bhd.

Ibrahim, M. L. M., Arip, M. A. S. M., \& Bistamam, M. N. (2014). Analisis Kesahan Kandungan Modul Penyesuaian Pemikiran Kerjaya (PKK) Berdasarkan Pendekatan Teori Cognitive Information Proessing (CIP), 7, 52-67. 
INTERNATIONAL JOURNAL OF ACADEMIC RESEARCH IN BUSINESS AND SOCIAL SCIENCES

Vol. 9, No. 7, July, 2019, E-ISSN: 2222-6990 ¿ 2019 HRMARS

Konting, M. M. (2000). Kaedah Penyelidikan Pendidikan. Kuala Lumpur: Dewan Bahasa dan Pustaka.

Konting, M. M. (1990). Kaedah penyelidikan pendidikan. Kuala Lumpur: Dewan Bahasa dan Pustaka.

Lawshe, C. H. (1975). A quantitative approach to content validity. Personnel Psychology, 28(4), 563-575.

Lynn, M. R. (1986). Determination and quantification of content validity. Nursing Research, 35, 382- 385 .

Noah, S. M., \& Ahmad, J. (2005). Pembinaan Modul: Bagaimana Membina Modul Latihan dan Modul Akademik. Serdang: Penerbit Universiti Putra Malaysia

Othman, M. (2015). Penulisan Thesis dalam Bidang Sains Sosial Terapan, Edisi Ke-4. Serdang : Penerbitan Universiti Putra Malaysia.

Othman, H., Salleh, M., Berhannudin, Abdullah, S., al-Edrus, S. M. D., \& Sulaiman, A. (2008) Perlaksanaan pendekatan pembelajaran berasaskan pengalaman (PBL dan POPBL) bagi meningkatkan kemahiran insaniah pelajar. In: Seminar Kebangsaan Kemahiran Insaniah dan Kesejahteraan Sosial (SKIKS) 2008, 18-19 Ogos, 2008, Hotel Mahkota, Melaka.

Rubio, D. M., Berg-Weger, M., S.Tebb, S., Lee, E. S., \& Rauch, S. (2003). Objectifying content validity: conducting a content validity study in social work research. Social Work Research, 27(2), 94105.

Rusell, J.D. (1974). Modular Instruction: A Guide to the Design, Selection, Utilization and Evaluation of Modular Materials. United States: Publishing Company.

Yahya, S. Y. S. (2015). Kesahan Modul Kelompok Pembangunan Diri Menggunakan Aplikasi NeuroLinguistic Programming (NLP). (Disertasi Master, Universiti Pendidikan Sultan Idris). 